\title{
¿POR QUÉ LOS PRECIOS DE LOS HOTELES PUEDEN TENER DIFERENCIAS SEGÚN EL PAÍS EN EL QUE SE ENCUENTREN?
}

\author{
MARÍA ILLESCAS-MANZANO \\ Departamento de Economía y Empresa, UNIVERSIDAD DE ALMERIA, ESPAÑA \\ e-mail: mim434@ual.es \\ MANUEL SANCHEZ-PEREZ \\ Departamento de Economía y Empresa, UNIVERSIDAD DE ALMERIA, ESPAÑA \\ e-mail: msanchez@ual.es \\ SERGIO MARTINEZ-PUERTAS \\ Departamento de Economía y Empresa, UNIVERSIDAD DE ALMERIA, ESPAÑA \\ e-mail: spuertas@ual.es.
}

\section{RESUMEN}

Nuestro estudio consiste en realizar una comparativa de 3.084 hoteles de diferentes ciudades de dos países (España y Francia) e identificar cuáles son los factores determinantes que más influyen en la fijación del precio del hotel de cada país analizando sus semejanzas y diferencias. Empleamos modelos hedónicos de precios basados en estimación por mínimos cuadrados (MCO) y en estimación por regresión cuantílica. Los resultados obtenidos tanto por MCO como por regresión cuantílica confirman que la categoría de hotel es una señal de calidad más fuerte en Francia que en España mientras que el eWOM tiene más influencia en el precio de habitación en España que en Francia. En ambos países el efecto de la concentración hotelera es positivo sin evidencia de diferencias significativas en ambos países.

Palabras clave: Ewom, competencia, categoría de hotel, comparativa fijación de precios y regresión cuantílica.

\section{Why pricing hotel can have differences according to the country in which it is found?}

\begin{abstract}
Our study consists of comparing 3,084 hotels in different cities of two countries (Spain and France) and identifying which are determinate factors that most influence in fixing price hotel of each country, analyzing their similarities and differences. We use hedonic pricing models based on least squares estimation (OLS) and quantile regression estimation. The results obtained by both OLS and quantile regression confirm that hotel category is a stronger quality signal in France than in Spain while eWOM has more influence on the room price in Spain than in France. In both countries, the effect of hotel concentration is positive without evidence of significant differences in both countries.
\end{abstract}

Keywords: Ewom, competition, hotel category, comparative pricing hotel and quantile regression.

Clasificacion JEL: C51 y M31 


\section{INTRODUCTION}

The price is a prime variable of study that influences the choice of hotel accommodation (Lockyer 2005) where such prices are influenced by a series of factors associated with the country of location hotel such as economic performance, terrorist attacks and the number of tourists entering the country (Lee 2011), their culture aspects, social and labor (Nankervis and Debrah, 1995 ), efficiency in production (Jones and Romer, 2009), assessment of the perception of the service received at the hotel (Poon and Low, 2005) and how to manage sales channels tradition and current (Stangl et al., 2016). In addition to differences in the management of environmental standards (Douglas and Glen, 2000, Zenget al., 2007, Karapetrovic and Casadesús, 2009) and in the management of property and the hotel category from one country to another (Pine and Phillips, 2005). The main objective of our study is to answer the question why a hotel can have different prices depending on the country where hotel are found?, and more concretely it would be to know the behavior of the hotels at the time of fixing the price in the different countries of our study and see what determinants factors influence each of them.

Our work contributes first to analyzing the impact of eWOM, hotel category and competition in hotel prices in two European countries, Spain and France, analyze if country influence on pricing. Second makes a comparison between countries of study of the determinants of the price and identifies which determinant factors influence more in pricing in each country study and analyze their differencessimilarities between the two countries. Third compare 3.084 hotels in different cities of two countries in 113 destinations in Spain and France or organized in 743 commercial areas and find out what are the factors that influence more in one country or another. Fourth we provide more universal research by working with cities in two countries to serve the management of hotels. Fifth, we can study if the results of one country are extrapolated to another and viceversa. Last, we provide a more complete modeling by means of quantile regression.

To contrast the effect of the category, eWOM and competition in the room price, and to contrast the possible differences between the two countries, we will use hedonic models of prices based on least squares estimation (OLS) and quantile regression estimation. is a recommended technique for the study of asymmetric variables and distributions of heavy tails (Koenker and Bassett, 1978) where the ordinary least squares method can produce erroneous estimates. In addition, the quantile regression allows analyzing if the effect of a certain factor is not constant throughout the distribution of the hotel price.

In our knowledge, our work is the first to carrying that makes a comparison between countries of the determinants of the hotel price in order to obtain more universal conclusions by quantile regression, allowing modeling of the price of most complete suite that provided by MCO and allows to analyze if a certain factor has a non-constant effect throughout the conditioned distribution of the room price.

\section{STUDY OF THE LITERATURE}

\subsection{Study the price as the dependent variable}

Due to globalization, tourism sector encounters numerous opportunities and difficulties for international management of your business (Luthans and Doh 2012) so that fixing the price of a room for the manager is a decision of maximum relevance in marketing mix strategy, being the only element that directly impacts in income ( Chen and Rothschild 2010), widely used for his flexibility at the time to make strategic decisions in marketing (Espinet et al ., 2003) .

Hotel attributes and location (Bull 1994 , Espinet et al ., 2003 ), star category and hotel chain membership (Israeli 2002, Becerra et al ., 2013) , c Local opetition (Becerra et al., 2013), LED TV availability, availability of facilities for confe rences and location (Chen and Rothschild 2010), evaluating the quality of a tribute-eWOM (Zhang et al., ( 2011 ) and Pawlicz and Napierala (2017), 
online reputation (Abrate and Viglia 2016), the size d e 1 hotel, the number of staff, type of hotel and the proportion of foreign tourists (Hung et al. , 2010), advance, duration, realization, use of indirect channels, number of people making the reservation and star category (Masiero et al. , 2015) and the imbalance of the Chen and Chiu market (2014) have been studied to fix the hotel prices being their efects that a higher category of stars, less distance to the center and availability of restaurant $\mathrm{e}$, the prices increase ( Bull 1994), as the star category, hotel size, city, availability of parking, and distance to the beach influence the price (Espinet et al ., 2003), there is an influence of the category of stars in the price (Israeli 2002), the category of stars has a significant effect on the price greater than belonging to a chain and that the local competition negative effect, with the effect of category strongest stars the more competition increases (Becerra et al 2013), and T here are differences in factors influencing the price of room as the reserve day (weekday / weekend ) so that during the week, Internet access and gym availability are positively influenced and on weekends the room size (Chen and Rothschild 2010), and $1 \mathrm{eWOM}$ effect is significant and positive in the room price (Zhang et al. , 2011, Pawlicz and Napierala 2 017), c OW online reputation acquires weight on the star rating in dynamic contexts price (Abrate and Viglia 2016), $\mathrm{p}$ ara high price levels, both the proportion of foreign tourists as the hotel are significant determinants of price and its impact is positive while the number of staff per room the size of the hotel are determining significant and positive influence on all price levels except at the lowest level (Hung et al. 2010), 1 to advance booking and date of stay in summer season along with the category of star gives rise to a price increase, providing an opposite effect using indirect channels and the number of people performing the reservation (Masiero et al. 2015) and surplus demand has a positive effect and signific prices (Chen Chiu 2014 ) .

We have not found none to make a comparison of factors (ewom, category and competence) in different countries and analice differences and similarities and establish a pattern of behavior that will help the hotel management to make its own decisions when setting the hotel price.

So that our work provides several contributions, on the one hand it is a new contribution of the anticyclical regression in the hotel sector applied to the comparison of the hotel sector between Spain and France and also a new contribution to expand the comparative study between both countries on the effect of eWOM and on the competition and see what are the determinants that influence each pa ountries are. Additionally, our work provides new evidence on the effect of the hotel category as a quality signal, analyzing in the first place if its effect is not constant and depends on the price level and secondly analyzing if its effect is more intense in any of the two countries of study.

\subsection{Hotel category}

Hotel category is the most important feature (Espinet et al., 2003 and Zhang et al., 2011) and one of the most studied in the academic literature for the establishment of hotel prices as analyzed by Bull (1994) and Israeli (2002) demonstrating both that category of hotel has a positive pricing for the hotel room influence. Even in dynamic pricing strategies, the hotel category is a significant factor influencing price (Abrate et al., 2012) since it allows maintaining stable prices when the hotel category is high and the trend of price decreases and raise the price when the trend grows so that a hotel with high categories can increase its income (Abrate et al., 2012).

In other effect on the price of the room, the hotel category also influences other attributes associated with quality s, which are linked positively with the price (Abrate et al., 2011).

Our study on the category of hotel tries to provide two additional contributions. The first, at a general level, is to analyze if the effect of the category is different according to the price level considered. The second contribution is to compare the effect of a category in Españ and France with the objective of analyzing if the hotel category considered as a quality signal has greater intensity in any of the countries included in the study. 


\section{3. eWOM}

Generalized use of IT tools, Internet for information search and way client communicates has increased (Ip et al., 2011), where eWOM has significantly influenced how client behaves, especially in the tourism sector (Cantallops Y Salvi, 2014), eWOM is considered as credible and reliable (MatuteVallejo et al., 2015, Tang et al., 2014). Therefore, understanding the consequences of eWOM on revenues or prices is of vital importance for the strategic direction of the tourism sector. To what we have been able to identify the effects found are that influye directly on business results (Nieto et al., 2014). There is a positive effect of online assessments on the number of evaluations conducted (Ye et al., 2009), the comentary provided positive customer results in a prim to the price (Yacouel and Fleischer, 2012) and directly influence the reputation of tourism enterprises (Baka 2016). There is a positive relationship between eWOM and employment in the hotel sector (Viglia et al., 2016) and there is a positive relationship of the price marked by the hotel itself and the client's willingness to pay for the accommodation (Nieto-García et al., 2017).

All these studies, highlight how the comments published about a hotel have a decisive influence when it comes to setting the price of hotel rooms and our work also wants to analyze, stepping more by investigating how the hotel country can influence the results obtained since eWOM is becoming a key piece of the place's reputation (Gretzel and Yoo 2008, Chen 2008, Ógür and Onur Tas 2012) and tourist destinations influence positively in the attitude of foreign tourists visiting the destination (Wang 2015)

\subsection{Competition}

In the literature there are limited studies that deepen how the competition influences the price of the hotel. We highlight how room rate increases if there is little room availability between direct competitors (Abrate et al., 2012), the level of local competition has a negative effect on prices and the positive effect of the hotel category is increased when local competition increases. So the hotel categories is a sign of more intense quality when the agglomeration of competitors is stronger (Becerra et al., (2013), there is a positive relationship between the number of activities offered in an area and the economic impact on each, the theory of the central place (Daniels, 2007). In addition, there are conflicting results about the effect of hotel concentration on the performance of the company. On the one hand, Canina et al., 2005; and Chung and Kalnins, 2001 consider that the relationship is positive while Folta et al., 2006; Marco-Lajara et al., 2014 and Ki and Jang 2015, consider that the relationship is negative. In addition, Balaguer and Pernías, 2013, conclude that the relationship between hotel concentration and price is negative, and that the incorporation of a new competitor in the area leads to a significant reduction in the price, with days still lower weekdays with the same quality at the hotel.

Due to the contradictory results on the relationship between hotel concentration and performance and the relationship between hotel concentration and price, our work wants provide new evidence on the effect of hotel concentration on the price. In this way, we intend to analyze if there are differences in the effect of the hotel concentration according to the country of location of the hotel and if the effect of the hotel concentration is different, according to the hotel price level.

\section{METODOLOGÍA}

Hotel database has been obtained by combining web analysis techniques together with the information system of a tourist intermediary. With the aim of analyzing which determining factors can influence the prices of rooms in the Spanish and French hotel sector and also what differences exist between both hotel sectors, we will consider different hedonic models of prices. First, an initial sample of 8,004 hotel establishments located in Spain and France was obtained. Due to the existence of hotels included in the initial sample that presented missing data, the final sample size was reduced to 3,084 
hotels distributed in 66 destinations or locations in Spain, organized in 625 commercial areas and in 47 destinations in France, organized in 118 commercial areas. The commercial areas considered are those provided by the tourist intermediary.

The room price analyzed in the study corresponds to the price of a standard double room and due to the variations that the room price may cause due to different causes (season, occurrence of events) we have considered the annual average of the price in euros for a double room as a variable dependent on the hedonic model. Regarding the explanatory variables considered in the model, we have considered:

- Variable X 1 = Country. To incorporate the country in which the hotel operates, we have considered the dummy variables corresponding to France, with Spain being the reference category.

- Variable X 2 = Category. This variable measures the number of stars (from 1 to 5) obtained by the hotel and represents the quality level of the hotel based on the different regulations of the locations considered in the sample. Based on the study by Becerra et al (2013), the variable is included in the model as a numeric variable.

- Variable X $3=\mathrm{eWOM}$. This variable collects the average valuation made by the clients of each public hotel given in the web portal (Zhang et al 2011) and represents a measure of the reputational level reached by the hotel.

- Variable X $4=$ Hotel No. s. From Becerra et al. (2013), this variable is a first indicator of the level of competence of a hotel establishment and for each hotel, the number of hotels of the same category that are in its commercial area. The reason for considering the commercial area as a geographic area of competition is due to the different geographical size of the 113 locations included in the final sample and also to the fact that the hotels located within each zone are considered commercially homogeneous within their category. Therefore, the use of commercial areas as an area of competence allows homogenizing the possible differences between the geographical areas included in the sample.

- Variable X 5 = Distance. This variable represents the second indicator of the level of competence of a hotel and measures the average distance in kilometers of a hotel with respect to hotels in its area, which belong to the same category (Becerra et al., 2013). For the measurement of this variable we have used programming routines in R based on the GPS coordinates of each establishment.

All the statistical analysis techniques and procedures, carried out in this study, have been developed using the software R Version 3.5.1.

Table 1 shows the percentage of hotels in the sample by Category and Country, while Table 2 shows the main descriptive statistics of the continuous variables included in the study.

Analogously to most previous studies on determinants of the hotel price, a hedonic price model has been considered semi-logarithmic, so that LPRECIO denotes the neperian logarithm of the price. Thus, by means of the semi-logarithmic model, the percentage of impact on the price corresponding to an increase in one unit of a continuous explanatory variable is equal to its corresponding coefficient $\beta$ i multiplied by 100 , while for a dummy variable said percentage of influence must be calculated by

$$
100 \cdot\left(e^{\beta_{i}}-1\right)
$$


TABLE 1

Percentage of establishments by category of each country

\begin{tabular}{|l|c|c|}
\hline Category/Country & Spain & France \\
\hline $\mathbf{1}^{*}$ & 3.782 & 1.399 \\
\hline $\mathbf{2}^{*}$ & 12.779 & 25.350 \\
\hline $\mathbf{3}^{*}$ & 35.311 & 50.3497 \\
\hline $\mathbf{4}^{*}$ & 44.626 & 22.028 \\
\hline $\mathbf{5}^{*}$ & 3.503 & 0.874 \\
\hline
\end{tabular}

Source: own elaboration (2018)

TABLE 2

Descriptive statistics of continuous variables

\begin{tabular}{|c|c|c|c|c|c|}
\hline Variable & Half & D.Typical & Median & Mín & Máx \\
\hline Category & 3.247 & 0.865 & 3 & 1 & 5 \\
\hline eWOM & 7.443 & 1.111 & 7.6 & 0.2 & 10 \\
\hline $\mathbf{N}^{\mathbf{0}}$ Hoteles & 17.93 & 32.190 & 6 & 1 & 150 \\
\hline Distance & 1.616 & 1.914 & 1.095 & 0 & 17.920 \\
\hline Price & 80.19 & 63.434 & 65.21 & 20.45 & 1224 \\
\hline
\end{tabular}

Source: own elaboration(2018)

where $\beta \mathrm{i}$ presents the coefficient associated with the dummy variable (Halvorsen and Palmquist 1980). In this way, since our objective is on the one hand to analyze the determinant factors of prices in hotels in Spain and France and on the other hand to analyze if there are differences between both countries in the effect of these determinants, we have considered two hedonic models of prices. The first model only incorporates the explanatory variables in the model and is given by:

$$
\text { LPRECIO }=\beta_{0}+\sum_{i=1}^{p=5} \beta_{i} X_{i}+
$$

In order to analyze what factors influence the price of the room, we intend to estimate the model (1) using hotel establishments in both Spain and France. Now, the estimation of the first model allows us to analyze in a global way the determinants of the hotel price in both countries but it does not allow us to analyze if there are differences between both sectors and with the objective of analyzing this issue a second model is proposed that incorporates the effects of interaction between the Country variable and the rest of explanatory variables, which is given by:

$$
\text { LPRECIO }=\beta_{0}+\sum_{i=1}^{p=5} \beta_{i} X_{i}+\sum_{i=2}^{p=5} \alpha_{i}\left(X_{i} \cdot X_{1}\right)
$$

With the estimation of the second model and more specifically with the estimation of the coefficients ai corresponding to the terms of interaction with the hotel country, we can analyze if there are significant differences in the effect of an explanatory variable on the price between France and Spain (Schepers, 2016). Specifically, both the estimation of the model (1) and the model (2) will be carried out using the least squares method (OLS). 
First, let's compare if the model (2) that incorporates interactions is more appropriate than the model (1), and for this we will carry out the contrast of the coefficients $\alpha$ i associated with the interactions:

$$
\left\{\begin{array}{c}
H_{0}: \alpha_{i}=0 \forall i \\
H_{1}: \alpha_{i} \neq 0 \text { para algún } i
\end{array}\right.
$$

The acceptance of the null hypothesis of the previous model supposes accepting that the model (2) is not more appropriate than the model (1) and therefore there would be no differences between France and Spain in the effects of each explanatory variable on the price. On the other hand, the rejection of the null hypothesis is equivalent to accepting that there are differences between the French and Spanish hotel sector.

As a step prior to the realization of the contrast, we analyzed whether there is multicollinearity between the explanatory variables by means of the value of the inflation factor of variance (IVF). In this way, it was observed that among the explanatory variables corresponding to the first model there are no problems of multicollinearity since in all cases the IVF values are below 1.2. On the other hand, if we analyze the multicollinearity of the second model if we see multicollinearity in the coefficients of the interactions, since the IVF values are above 10 . Therefore, we have decided to typify the four continuous explanatory variables considered in both models and with it the multicollinearity problems of the second model disappear because the IVF values are below 1.9.

Thus, the previous contrast will be made based on the models (1) and (2) with the standardized continuous variables. The result of the contrast (Test F, ANOVA) provides a p-value equal to 0.0002337 and therefore the model (2) is significantly more adequate, at level 0.001 , than the model (1) and therefore we accept that there are significant differences between the French and Spanish sector. In order to analyze these differences, Table 3 provides the model coefficients (2) estimated by OLS. Table 3 also provides the model estimate (1) for comparative purposes.

TABLA 3

Ols estimation of models (1) and (2)

\begin{tabular}{|l|c|c|}
\hline \multicolumn{2}{|c|}{ Ols estimation of models (1) and (2) } \\
\hline Constant & $4.1623^{* * *}$ & Modelo 2 \\
\hline Country & $0.4804^{* * *}$ & $4.1617^{* * *}$ \\
\hline Category & $0.1433^{* * *}$ & $0.4930^{* * *}$ \\
\hline eWOM & $0.0558^{* * *}$ & $0.1290^{* * *}$ \\
\hline $\mathbf{N}^{\mathbf{0}}$ Hotel & $0.0951^{* * *}$ & $0.0735^{* * *}$ \\
\hline Distance & $-0.0490^{* * *}$ & $0.0946^{* * *}$ \\
\hline Category*Country & & $-0.0442^{* * *}$ \\
\hline eWOM* Country & & $0.0783^{* * *}$ \\
\hline $\mathbf{N}^{\mathbf{0} H o t e l s * C o u n t r y}$ & & $-0.0491^{* *}$ \\
\hline Distance* Country & & -0.0201 \\
\hline $\mathbf{R}^{\mathbf{2}}$ & 0.3005 & -0.0190 \\
\hline $\mathbf{R}^{2}$ ajusted & 0.2994 & 0.3054 \\
\hline$*$ Significant at the 5\% level & & 0.3034 \\
\hline$* *$ Significant at the 1\% level & & \\
$* * *$ Significant at 0.1\% level & & \\
\hline
\end{tabular}

Source: own elaboration (2018)

With respect to the results obtained with the first model, we can observe that the five explanatory variables have a significant effect on the hotel price in France and Spain. On the other hand, through the results of the model (2) we can observe that there are significant differences between France and 
Spain in the effect of the Category and eWOM variables on the price while the effect of the variables related to the competition ( $\mathrm{N}^{\circ}$ Hotels, Distance) does not present significant differences between both countries.

Once we have verified that there are differences between France and Spain, in the effect of several explanatory variables on the room price, next we will estimate the model (1) for the hotels in Spain and France individually, that is, we will obtain the model (1) only using the Spanish hotels and the model (1) only using the French hotels, so that on this occasion the Country variable is excluded from the model (Table 4). Analogously to the previous models, it was found that there are no problems of multicollinearity between the explanatory variables both for the data from Spain and for the data from France and therefore, on this occasion we will obtain the models with the unstandardized variables.

TABLE 4

Estimation by OLS of the model (1) for Spain and France

\begin{tabular}{|l|c|c|}
\hline & Spain & France \\
\hline Constant & $3.1700^{* * *}$ & $3.7254^{* * *}$ \\
\hline Category & $0.1490^{* * *}$ & $0.2395^{* * *}$ \\
\hline $\mathbf{N}^{\mathbf{0}}$ Hotel & $0.0662^{* * *}$ & $0.0220^{*}$ \\
\hline Distance & $0.0029^{* * *}$ & $0.0023^{* *}$ \\
\hline $\mathbf{R}^{\mathbf{2}}$ & $-0.0231^{* * *}$ & $-0.0330^{* * *}$ \\
\hline $\mathbf{R}^{2}$ ajusted & 0.2074 & 0.225 \\
\hline$*$ Significant at the 5\% level & 0.2061 & 0.2195 \\
$* *$ Significant at the 1\% level & \\
$* * *$ Significant at $0.1 \%$ level & \\
\hline
\end{tabular}

Source: own elaboration (2018)

The results obtained with Spain and France confirm the significant effect of the Category, eWOM, $\mathrm{N}^{\mathrm{o}}$ Hotels and Distance. Thus, an increase in one star of the category increases the room price by $14.90 \%$ in Spain while in France it translates into an increase of $23.93 \%$ of the price, this difference being significant (Table 3, Model 2). This confirms that in France the hotel category is a stronger signal of quality than in Spain. On the other hand, an increase in one point in the average valuation made by customers allows to increase the room price by $6.62 \%$ in Spain while in France the increase over the price is significantly lower (Table 3, Model 2), specifically 2.2\%. This shows that in Spain the eWOM has more weight in the pricing than in France. Finally, given that $\mathrm{N}^{\circ}$ Hotels has a positive effect and Distance has a negative effect, both in Spain and in France, the agglomeration or concentration of competitors in a commercial area has a positive effect on the price. More specifically, the appearance of a new competitor of the same category in the commercial area represents an increase of $0.29 \%$ in the room price in Spain, while in France the increase is $0.23 \%$, although the difference is not significant (Table 3, Model 2). With respect to the average distance between competitors, the decrease in one kilometer of the average distance between competitors in the same category of a commercial area means an increase of $2.31 \%$ in the price of a room in Spain and 3.3\% in France, the difference being no significant (Table 3, Model 2).

Once the comparison of the determinant factors of hotel prices between France and Spain by means of OLS was made, we decided to analyze the possible differences by means of quantile regression, which is an appropriate method for the analysis of asymmetric variables and long tail distributions because the method ponders the observations (Koenker andBassett, 1978). In addition, the OLS method provides estimates of the conditioned average, while the quantile regression provides 
estimates of conditioned quantities and, therefore, allows to analyze non-constant effects of the explanatory variables on the dependent variable, in this case the price of room. Thus, the highest room price observed in the sample is sixty times greater than the minimum price observed, which suggests an asymmetry of the hotel price distribution with what we have considered the estimate using thequantile regression application.

As with the OLS method, the first step of the analysis with quantile regression will be to analyze the possible differences between model (1) and model (2) through the Wald test proposed in Koenker and Bassett (1982b). To analyze possible differences between France and Spain along the entire distribution price, we will make the Wald test for percentiles10, 25, 50, 75 and 90 of the distribution room price (Masiero et al., 2015) and whose results are included in Table 5.

TABLE 5

Wald test, significant differences models (1) and (2)

\begin{tabular}{|l|c|}
\hline Cuantil & p-valor Test de Wald \\
\hline $\mathbf{0 . 1}$ & 0.2621 \\
\hline $\mathbf{0 . 2 5}$ & $1.269 \mathrm{E}-4^{* * *}$ \\
\hline $\mathbf{0 . 5}$ & $1.126 \mathrm{E}-10^{* * *}$ \\
\hline $\mathbf{0 . 7 5}$ & $7.856 \mathrm{E}-6^{* * *}$ \\
\hline $\mathbf{0 . 9}$ & 0.1974 \\
\hline$*$ Significant at the $5 \%$ level \\
$* *$ Significant at the $5 \%$ level \\
$* * *$ Significant at the $1 \%$ level \\
Source: own elaboration (2018)
\end{tabular}

In this way, the Wald test allows us to group the quantiles into two groups, those quantiles where there are no significant differences between the model (1) and (2) and therefore there are no significant differences in the impact of the determinants on the price. between both countries and the second group formed by those quantiles where there are significant differences between France and Spain. In the first group is formed by the 10th and 90th percentiles and for these price levels we will only analyze the model (1), while the second group would be formed by the 25th, 50th and 75th percentiles for which we will analyze the model (2) that allows us through interactions to detect differences between both countries. First we start with the estimation of the model (1) for the quantiles 0.1 and 0.9. Since in the model (1) there are no problems of multicollinearity, we will use the original variables without standardizing in the estimation of the model (1). Table 6 provides the estimation of the model (1) for the 10th and 90th percentiles. or quantile regression and also provides the $\mathrm{p}$-value of the Wald test for the equality of coefficients between both percentiles to analyze possible differences between both price levels (Koenker and Bassett 1982a).

The results provided by Table 6 show for both price levels the significant effect of all the explanatory variables analyzed, confirming the positive effect of the category, the eWOM, the number of competitors in the commercial area and the negative effect of the average distance between competitors for the two countries of study, which together with the previous effect confirms the positive effect of the concentration of competitors in the same commercial area. There is also a country effect, so that for both percentiles French hotels are more expensive than Spanish hotels. Additionally, the Wald test allows us to analyze if there are differences in the impact produced by each explanatory variable according to the price level analyzed. In this way, we see that the effect of eWOM, the number of competitors and distance is similar for both percentiles while the effect of the category is significantly 
different, producing a price increase of $14.88 \%$ for the 10th percentile and an increase of $19.91 \%$ for the 90 th percentile. Country effect is significantly non-constant with French prices being $43,264 \%$ more expensive for the 10th percentile and $71.69 \%$ more expensive for the 90th percentile.

TABLE 6

Quantitative Regression Estimation of the model (1)

\begin{tabular}{|l|c|c|c|}
\hline & \multicolumn{3}{|c|}{ Model1 } \\
\hline & $\mathbf{0 . 1}$ & $\mathbf{0 . 9}$ & Test de Wald \\
\hline Constant & $2.9339^{* * *}$ & $3.5516^{* * *}$ & \\
\hline Country & $0.3595^{* * *}$ & $0.5405^{* * *}$ & $1.364 \mathrm{E}-6^{* * *}$ \\
\hline Category & $0.1488^{* * *}$ & $0.1991^{* * *}$ & $0.0061^{* *}$ \\
\hline eWOM & $0.0474^{* * *}$ & $0.0481^{* * *}$ & 0.9511 \\
\hline $\mathbf{N}^{\mathbf{0}}$ Hotel & $0.0027^{* * *}$ & $0.0027^{* * *}$ & 0.8380 \\
\hline Distance & $-0.0213^{* * *}$ & $-0.0244^{*}$ & 0.7466 \\
\hline
\end{tabular}

* Significant at the $5 \%$ level

** Significant at the $1 \%$ level

*** Significant at the level of $0.1 \%$

Source: own elaboration (2018)

Next, Table 7 provides the estimation of the model (2) for those quantiles where there are differences between countries and where we have used standardized variables since the interactions produced problems of multicollinearity.

TABLE 7

Quantitative Regression Estimation of the model (2)

\begin{tabular}{|l|c|c|c|}
\hline \multicolumn{3}{|c|}{ Quantitative Regression Estimation of the model (2) } \\
\hline & $\mathbf{0 . 2 5}$ & $\mathbf{0 . 5}$ & $\mathbf{0 . 7 5}$ \\
\hline Constant & $3.9268^{* * *}$ & $4.1061^{* * *}$ & $4.31698^{* * *}$ \\
\hline Country & $0.4569^{* * *}$ & $0.5580^{* * *}$ & $0.59781^{* * *}$ \\
\hline Category & $0.1195^{* * *}$ & $0.1254^{* * *}$ & $0.13159^{* * *}$ \\
\hline eWOM & $0.0734^{* * *}$ & $0.0863^{* * *}$ & $0.08461^{* * *}$ \\
\hline $\mathbf{N}^{\mathbf{0} H o t e l s}$ & $0.1082^{* * *}$ & $0.1193^{* * *}$ & $0.11002^{* * *}$ \\
\hline Distance & $-0.0531^{* * *}$ & $-0.056^{* * *}$ & $0.05160^{* * *}$ \\
\hline Category*Country & $0.0778^{* *}$ & $0.1291^{* * *}$ & $0.09209^{* * *}$ \\
\hline eWOM*Country & $-0.0547^{* *}$ & $-0.0948^{* * *}$ & $-0.07245^{* * *}$ \\
\hline $\mathbf{N}^{\mathbf{0} H o t e l s * C o u n t r y}$ & -0.0198 & -0.0387 & $-0.07159^{*}$ \\
\hline Distance*Country & -0.0155 & -0.0386 & -0.04080 \\
\hline$*$ Significant at the 5\% level \\
** Significant at the 1\% level \\
$* * *$ Significant at 0.1\% level
\end{tabular}

Source: own elaboration (2018)

The results obtained in Table 7 show that the country effect is significant for the three percentiles analyzed and that in the 25th and 50th percentiles, there are significant differences between France and Spain in the effect of the category and the eWOM, if well at the 25th percentile these differences are significant at the $1 \%$ level while for the 50th percentile this difference is significant at the $0.1 \%$ level. 
In both cases, it can be seen that the effect of the category is more intense in France while the eWOM effect is stronger in Spain. For both price levels there are no significant differences in the effect of competition ( $\mathrm{N}^{\circ}$ Hotels, Distance) between the two countries. Likewise, for the 75 th percentile the effect of the category and of the eWOM present significant differences at the $0.1 \%$ level, with a greater impact on the effect of the category in France and a greater impact on the eWOM effect in Spain. In addition, the variable No. Hotels presents differences of effect between both countries at the level of $5 \%$, so that the number of competitors in the same commercial area has a positive effect on the more intense price in Spain than in France. In the three quantiles analyzed there are no differences of effect between France and Spain for the Distance variable.

Finally, once we have contrasted that there are differences in the effect between Spain and France of some explanatory variables, we will estimate the model (1) by means of quantile regression, without including the Country variable, for the hotels of Spain and France individually as we did with MCO, to deepen the differences between the two. Since for the model (1) there are no problems of multicollinearity, in this case we will also use the variables without typing. Table 8 provides the $p$-value of the Wald test for coefficient equality (Koenker and Bassett 1982a) between the 25th, 50th and 75th percentiles to analyze the existence of non-constant effects.

TABLE 8

Quantitative Regression Estimation of the model (1) for Spain and France

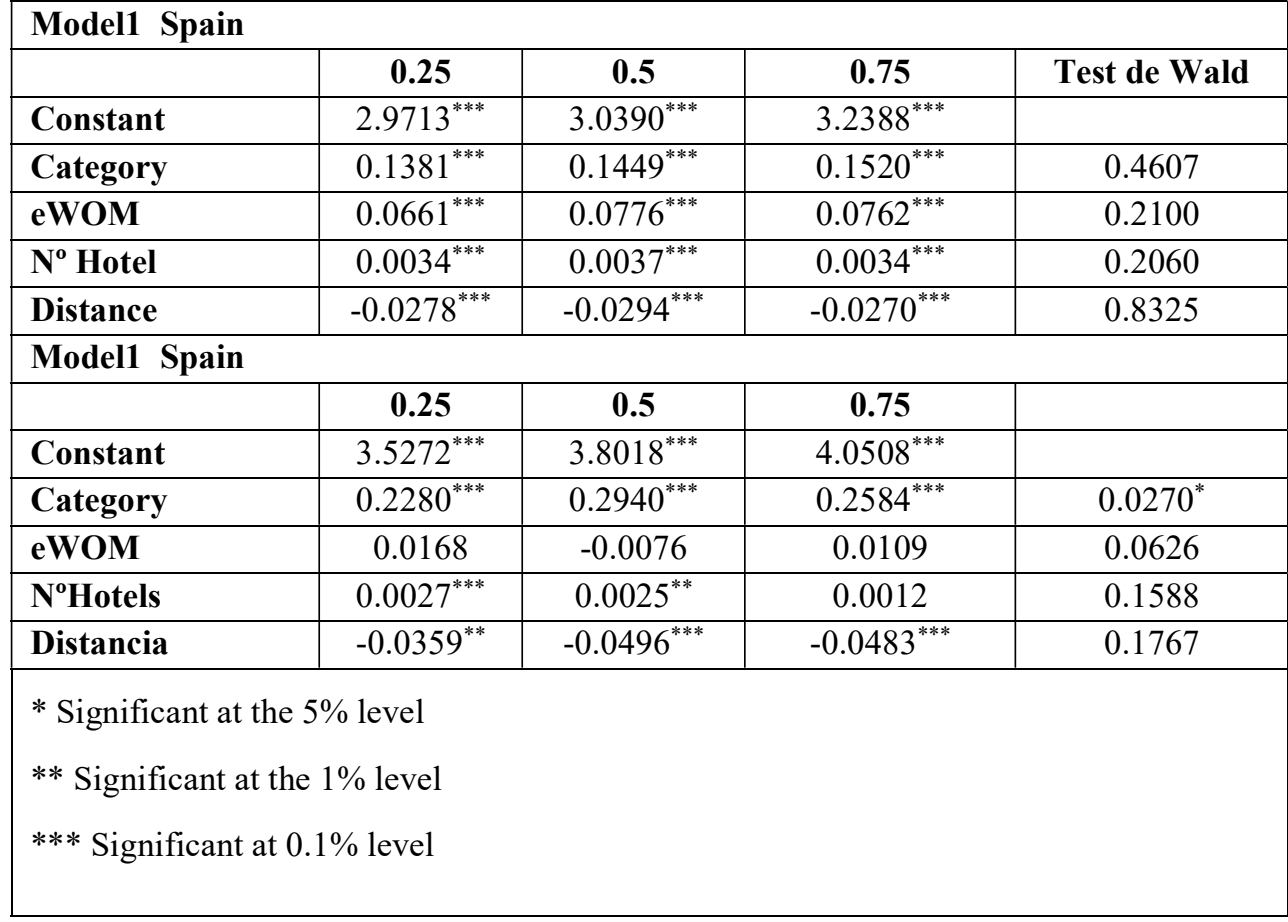

Source: ownelaboration (2018)

The results of Table 8 show that all the explanatory variables included in the model (1) have a significant effect on the price in Spain and also the results of the Wald test show that the effect of these variables is constant in Spain for the percentiles 25, 50 and 75. Additionally, in France all the explanatory variables, except the eWOM, have a significant effect on the price and only the effect of the category is not constant in France for the 25th, 50th and 75th percentiles.

In relation to the differences in the effect of the explanatory variables between Spain and France, we will start with the 25th percentile, where significant differences occurred in the effect of the category and the eWOM (Table 7). In this price level, in Spain the increase of one star in the category translates into an increase of $13.81 \%$ of the price in Spain while in France it produces an increase of $22.8 \%$. On 
the other hand, the increase of one point in the average valuation of the clients produces an increase of $6.61 \%$ in Spain while in France the effect of the eWOM is not significant. As for the number of competitors of the same category in the commercial area, the appearance of a new competitor in the same category means an increase of $0.34 \%$ in Spain and $0.27 \%$ in France, with the non-significant difference (Table 7). The reduction of one kilometer in the average distance between competitors of the same category in the commercial area increases the Spanish hotel price by $2.78 \%$ while in France the increase is $3.59 \%$, although also in this case the difference between countries is not significant (Table 7). Thus, the positive effect of the concentration of competition in both countries is confirmed for the 25th percentile.

For the 50th percentile, the positive effect of the concentration of competition for both countries is confirmed again and, in addition, this effect does not present significant differences between France and Spain (Table 7). Yes, there are significant differences between both countries in the effect of the category and the eWOM. Specifically, the increase of one star translates into an increase of $14.49 \%$ in Spain and $29.40 \%$ in France, while the unit increase in the average valuation of customers increases the Spanish price by $7.76 \%$ while in France the effect It is not significant.

Finally, for the 75th percentile, significant differences between Spain and France occur in the categories category, eWOM and number of competitors. A Yes, we have increased the unita river Spanish hotel category increases the price by $15.20 \%$ while France produces an increase of $25.84 \%$. In France the effect of the eWOM is not significant, while in Spain the increase in one point of the average valuation of the customer supposes an increase of $7.62 \%$ in the price. Similarly, the number of competitors has no significant effect in France, while in Spain the appearance of a new competitor in the same category means an increase of $0.34 \%$ in the price. The effect of the distance variable does not present significant differences between both countries and its effect is negative.

\section{CONCLUSIONES}

In the present work we have carried out a research on the determining factors in the establishment of hotel prices in Spain and France, as well as a comparison between both countries of the impact of each of the factors analyzed in order to contrast possible differences between the two hotel sectors. For this, the study is based on a large sample that covers 3,084 hotels located in 113 destinations in Spain and France. Specifically, the paper analyzes the impact of the country of location, of the hotel category, eWOM and concentration of competition on the price in hotels in Spain and France, and analyzes the possible differences between France and Spain of the effect of each of them. variables. For this we have considered the estimation of semi-logarithmic hedonic models using OLS and quantile regression.

The results obtained both by OLS as quantile regression show the significant effect of 1 country location so that the French hotels are more expensive than Spanish hotels. In relation to the other variables, the results by OLS show that all the variables have a significant effect in the two countries of study, while the quantile regression only confirms this issue for Spain, since for the hotels in France the significance of the effect of each one of the variables depends on the price level considered, which shows that there are differences between the two countries.

The results show a clear positive effect ofther hotel category in both countries, although the results obtained by MCO show that there is a significant difference in its effect between Spain and France, so that the effect of the category is greater in France. This difference in effect is also confirmed by quantile regression, for intermediate price levels (25,50 and 75 percentiles) while for the lowest (10th percentile) and highest (90th percentiles) level there are no significant differences in the effect of the category for both countries. This confirms that the hotel category is a sign of quality that has greater strength in France than in Spain. 
In relation to the effect of the eWOM, the results by MCO confirm its positive effect on the price and a significant difference between Spain and France, so that the valuation of consumers has greater effect in Spain than in France. The results obtained by quantile regression do not confirm this difference of effect for the lowest and highest price levels (10th and 90th percentiles) but for the intermediate price levels, where in addition the effect of the eWOM on the price no to be significant in France. In this way, Spanish hoteliers can increase their prices in line with the ratings received by their customers, while for French hotels this issue affects the lower and higher price levels.

The concentration of competition has a positive effect on the hotel price and also the results by MCO show that its effect does not present significant differences between both countries. This result is confirmed with quantile regression for all price levels, except for the 75th percentile, where the number of competitors of the same category in the commercial zone is no longer significant in France. In this way, the theory of the central place is confirmed, so that hotels are installed in an area where there are other hotels (and / or other tourist facilities) to attract more customers and increase profitability.

\section{REFERENCIAS BIBLIOGRÁFICAS}

ABRATE, G., CAPRIELLO, A. GIOVANNI, F. (2011). When quality signals talk: Evidence from the Turin hotel industry. Tourism Management, 32, 912-921.doi: 10.1016/j.tourman.2010.08.006

ABRATE, G., VIGLIA, G. (2016). Strategic and tactical price decisions in hotel revenue managment. Tourism Management, 55, 123-132.doi: 10.1016/j.tourman.2016.02.006

BAKA, V. (2016). Formative Reputation: From Being an Organizational Asset toBecoming a Process in The Making. Corporate Reputation Review, 19(2), 152-165.http://doi.org/10.1057/crr.2016.4

BALAGUER, J Y PERNÍAS, J, C (2013). Relationship between spatial agglomeration and hotel prices. Evidence from business and tourism consumers. Tourims Management 36,391-400

BECERRA, M., SANTALÓ, J., SILVA, R. (2013). Being better vs. being different: Differentiation, competition, and pricing strategies in the Spanish hotel industry. Tourism Management, 34,71-79.doi: 10.1016/j.tourman.2012.03.014

BULL, A., O. (1994). Pricing a motel's location. International Journal of Contemporary Hospitality Management, 6(6), 10-15.doi: 10.1108/09596119410070422

CANINA, L., ENZ, C.A., HARRISON, J.S. (2005). Agglomeration effects and strategic orientations: Evidence from the U.S. lodging industry. Academy of Management Journal,48(4), 565-581

CANTALLOPS, A. S., SALVI, F. (2014). New consumer behavior: A review of research on eWOM and hotels. International Journalof Hospitality Management, 36, 41-51.doi: 10.1016/j.jhm.2013.08.007

CHEN, C.M., CHIU, H.H., (2014). Research note: market disequilibrium effect on hotelprices. Tourism Economics 20(4), 901-909.doi: 10.5367/te.2013.0300

CHEN, Y., F. (2008). Herd behavior in purchasing books online. Computer in human behavior, 24(5),1977-1992. http://dx.doi.org/10.1016/j.chb.2007.08.004

CHUNG, W., KALNINS, A. (2001). Agglomeration effects and performance: A test of theTexas lodging industry. Strategic Management Journal, 22(10), 969-988

DANIELS, M.J. (2007). Central place theory and sport tourism impacts. Annals of Tourism Research 34(2), 332347

DOUGLAS, A., GLEN, D. 2000. Integrated management systems in small and medium enterprises. Total Quality Management 11(4-6), 686-690

ESPINET, J.M., SAEZ, M., COENDERS, G., FLUIVA., M. (2003) .Effect on prices of the attributes of holiday hotels: a hedonic price approach. Tourism Economics, 9, 165-177.doi: 10.5367/000000003101298330

GRETZEL, U., YOO, K., H.(2008). Use and impact of online travel reviews. In P. O'Connor W.

HOPKEN, U., GRETZEL.( Eds). Information and communication technologies in tourism (35-46). Wien/New York: Springer.

HALVORSEN, R., PALMQUIST, R. (1980). The interpretation of dummy variables in semilogarithmicequations. American Economic Review 70(3),474-475.

HUNG, W.T., SHANG, J.K., WANG, F.C. (2010). Pricing determinants in the hotel industry: Quantile regression analysis. International Journal of Hospitality Management 29, 378-384.doi: 10.1016/j.ijhm.2009.09.001

IP, C., LEUNG, R., LAW, R. (2011). Progress and development of information and communication technologies in hospitality. International Journal of Contemporary Hospitality Management, 23(4), 533-551.doi: 10.1108/09596111111130029

ISRAELI, A.A., (2002). Star rating and corporate affiliation: their influence on roomprice and performance of hotels in Israel. International Journal of Hospitality Management, 21(4), 405-424 doi: 10.1016/S0278-4319(02)000373

JONES, C.I., ROMER, P.M. (2009). The new kaldor facts: ideas, institutions, population and human capital. American Economic Journal: Macroeconomics, American EconomicAssociation 2(1), 224-45 
KARAPETROVIC, S., CASADESÚS, M. (2009). Implemeting environmental with other standardized management systems: Scope, sequence, time and integration. Journal of Cleaner Production, 17 (5), 533-540.

KI, S, L., JANG, S. (2015). Conditional agglomeration externalities in lodging markets. Journal of Hospitality and Tourism Research, 39, (4),540-559

KOENKER, R, BASSETT, G. (1978). Regression quantiles. Econometrica 46 (1), 33-50.

KOENKER, R Y BASSETT, G. (1982a). Robust tests for heteroscedasticity based on regression Quantiles. Econometrica 50, 43-61.

KOENKER R AND BASSETT G. (1982b). Tests of Linear Hypotheses and L1 Estimation. Econometrica 50, 15771583

LEE, C.G. (2011). The determinants of hotel room rates: another visit with Singapore's data. International Journal of Hospitality Management 30 (3), 756-758.

LOCKYER, T. (2005). The perceived importance of price as one hotel selection dimension. Tourism Management, 26 (4), 529-537.doi: 10.1016/j.tourman.2004.03.009

LUTHANS, F., DOH, J (2012). International Management: Culture, Strategy and Behavior, Mc Graw Hill Companies, Inc. pp. 116-118, 122-133.

FOLTA, T., COOPER, A.C., Y BAIK, Y. (2006). Geographic cluster size and firm performance. Journal of Business Venturing, 21(2), 217-242.

MARCO-LAJARA, B., CLAVER-CORTÉS, E., Y ÚBEDA-GARCÍA, M. (2014). Business agglomeration intourist districts and hotel performance. International Journal of Contemporary Hospitality Management, 26(8), 13121340.

MARCO-LAJARA, B., CLAVER-CORTÉS, E. ÚBEDA-GARCÍA, M Y ZAGAROZA-SÁEZ, P. (2016). A dynamic analysis of the agglomeration and performance relationship. Journal of Business Research, 69, 1874-1879.

MARÉ, D.C., GRAHAM, D.J. (2013). Agglomeration elasticities and firm heterogeneity. Journal of Urban Economics, 75, 44-56.

MASIERO, L., NICOLAU, J, L., Y LAW, R. (2015). A demand-driven analysis of tourist accommodation price: A quantile regression of room bookings. International Journal of Hospitality management, 50, 1-8.doi: 10.1016/j.tourman.2004.03.009

MATUTE-VALLEJO, J., POLO-REDONDO, Y., UTRILLA-ACERETE, A. (2015). Las características del boca-oído electrónico y su influencia en la intención de recompra online. Revista Europea de Dirección y Economía de la Empresa, 24(2), 61-75. http://doi.org/10.1016/j.redee.2015.03.002

NANKERVIS, A.R., DEBRAH, Y. (1995). Human resource management in hotels: A comparative analysis. Tourism Management 16(7), 507-513.

NIETO-GARCÍA, M., MUÑOZ-GALLEGO, P.A., GONZÁLEZ-BENITO, Ó. (2017).Tourists' willingness to pay for an accommodation: The effect of eWOM and internal reference price, International Journal of Hospitality Management, 62, 67-77.doi: 10.1016/j.ijhm.2016.12.006

NIETO, J., HERNÁNDEZ-MAESTRO, R. M. MUÑOZ-GALLEGO, P. A. (2014). Marketing decisions, customer reviews, and business performance: The use of the Toprural website by Spanish rural lodging establishments. Tourism Management, 45, 115-123. http://doi.org/10.1016/j.tourman.2014.03.009.

ÖGUT, H., ONUR, T, B, K. (2012). The influence of internet customer reviews on the online sales and prices in hotel industry. The Service Industries Journal, 32(2), 197-214. http://dx.doi.org/10.1080/0264069.2010.529436

PAWLICZ, A., NAPIERALA, T. (2017). The determinants of hotel room rates: an analysis of the hotel industry in Warsaw, Poland. International Journal of Contemporary Hospitality Management, 29, 571-588.Doi: 10.1108/IJCHM-12-2015-0694

PINE, R., PHILLIPS, P. (2005). Performance comparisons of hotels in China. International JournalofHospitality Management 24(1), 57-73.

POON, W.C, LOW, K.L.T. (2005). Are travellers satisfied with Malaysian hotels? International Journal of Contemporary Hospitality Management 17(3), 217-227.

SCHEPERS, J. (2016). On regression modelling with dummy variables versus separate regressions per group: Comment on Holgersson et al. Journal of Applied Statistics 43(4).

STANGL, B., INVERSINI, A., SCHEGG, R. (2016). Hotels' dependency on online intermediaries and their chosen distribution channel portfolios: Three country insights. International Journal of Hospitality Management 52, 8796.

TANG, T. (YA)., FANG, E. (ER)., FENG, WANG. (2014). Is Neutral Really Neutral? TheEffects of Neutral UserGenerated Content on Product Sales. Journal of Marketing,78(71328203), 41-58. http://doi.org/10.1509/jm.13.0301

VIGLIA, G., MARUI, A., Y CARRICANO, M. (2016). The exploration of hotel reference prices under dynamic pricing scenarios and different forms of competition. International Journal of Hospitality Management, 52, 46-55.doi: 10.1016/j.ijhm.2015.09.010

WANG, C.-C., LI, M.-Z., \& YANG, Y. Y. H. (2015). Multidisciplinary Social NetworksResearch: Second International Conference, MISNC 2015, Matsuyama, Japan, September 1-3, 2015. Proceedings. En L. Wang, S. Uesugi, I.H. Ting, K. Okuhara, \& K. Wang (Eds.), (pp. 448-459). Berlin, Heidelberg: Springer Berlin Heidelberg. http://doi.org/10.1007/978-3-662-48319-0_37

YACOUEL, N., Y FLEISCHER, A. (2012). The role of cybermediaries in reputation building and price premiums in the online hotel market. Journal of Travel Research, 51(2), 219-226.doi: 10.1177/0047287511400611

YE, Q., LAW, R., Y GU., B. (2009). The impact of online user reviews on hotel room sales. International Journal of Hospitality Management, 28, 180-182.doi: 10.1016/j.ijhm.2008.06. 
ZENG, S., SHI, J., LOU, G.A. (2007). Synergetic model for implementing an integratedmanagement system: An empirical study in China. Journal of Cleaner Production 15(18), 1760-1767.

ZHANG, Z., YE, Q., Y LAW, R. (2011). Determinants of hotel room price: an exploration of travelers' hierarchy of accommodation needs. International Journal of Contemporary Hospitality Management, 23(7), 972-981.doi: 10.1108/09596111111167551. 